\title{
Selection of raw cow's milk thermophilic lactic acid bacteria obtained from southwest Parana, Brazil, with potential use as autochthonous starter
}

\author{
Seleção de bactérias ácido-láticas termófilas de leite cru bovino \\ obtido no sudoeste do Paraná, Brasil, com uso potencial como \\ fermento autóctone
}

\author{
Simone Beux ${ }^{1 *}$ (D), Carla Todescatto ${ }^{1}$, João Francisco Marchi², Edimir Andrade Pereira ${ }^{1}$ \\ ${ }^{1}$ Universidade Tecnológica Federal do Paraná (UTFPR), Departamento de Química, Pato Branco/PR - Brasil \\ ${ }^{2}$ Universidade Tecnológica Federal do Paraná (UTFPR), Departamento de Engenharia de Alimentos, Francisco \\ Beltrão/PR - Brasil
}

*Corresponding Author: Simone Beux, Universidade Tecnológica Federal do Paraná (UTFPR), Departamento de Química, Via do Conhecimento, km 1, CEP: 85503-390, Pato Branco/PR - Brasil, e-mail: beuxsimone@gmail.com

Cite as: Beux, S., Todescatto, C., Marchi, J. F., \& Pereira, E. A. (2020). Selection of raw cow's milk thermophilic lactic acid bacteria obtained from southwest Parana, Brazil, with potential use as autochthonous starter. Brazilian Journal of Food Technology, 23, e2019070. https://doi.org/10.1590/1981-6723.17019

\begin{abstract}
This work aimed to isolate and identify Streptococcus and Lactobacillus species from raw cow's milk obtained from Southwest Paraná - Brazil. We used randomly amplified polymorphic DNA (RAPD)-PCR to identify and type 58 Streptococcus and 48 Lactobacillus isolates, of which 04 Streptococcus thermophilus and 02 Streptpcoccus macedonicus were confirmed by species-specific PCR and by sequencing of the $16 \mathrm{~S}$ ribosomal RNA of 02 Streptococcus lutetiensis/infantarius, 10 Lactobacillus fermentum, 03 Lactobacillus delbrueickii subspecies bulgaricus, 01 Lactobacillus rhamnosus/casei and 02 Lactobacillus helveticus. The results indicated predominance of Streptococcus thermophillus and Lactobacillus fermentum. Streptococcus thermophilus and Lactobacillus delbrueickii subspecies bulgaricus strains were tested on the basis of their acidification kinetics. Considerable variation between the Streptococcus thermophilus was observed for the maximum rate of acidification $\left(V_{m}\right)$, with a maximum of -4.5 and minimum of $-4.2 \mathrm{pH}$ milliunits $\mathrm{min}^{-1}$. The Lactobacillus delbrueickii subspecies bulgaricus showed values between -8.4 and $-7.1 \mathrm{pH}$ milliunits $\mathrm{min}^{-1}$. These results suggest that strains characterized as having a high acidifying capacity, could be used as starters in cheesemaking. The ferments presented an excellent performance in the acidification process, generating adequate curves, characteristics of a starter culture.
\end{abstract}

Keywords: Indigenours bacteria; Streptococcus; Lactobacillus.

\section{Resumo}

A proposta deste trabalho foi isolar e identificar espécies de Streptococcus e Lactobacillus a partir de leite cru de vaca coletado no sudoeste do Paraná, Brasil. A reação de amplificação aleatória de DNA polimórfico (RAPD)-PCR foi aplicada para identificação e tipificação de 58 Streptococcus e 48 Lactobacillus isolados, dos quais quatro 
Streptococcus thermophilus e dois Streptpcoccus macedonicus foram confirmados por PCR espécie-específica e, por sequenciamento do RNA ribossômico 16S, dois Streptococcus lutetiensis/infantarius, dez Lactobacillus fermentum, três Lactobacillus delbrueickii subespécie bulgaricus, um Lactobacillus rhamnosus/casei e dois Lactobacillus helveticus. Os resultados indicaram que os Streptococcus thermophillus e Lactobacillus fermentum foram predominantes. As estirpes Streptococcus thermophilus e Lactobacillus delbrueickii subespécies bulgaricus foram avaliadas de acordo com a cinética de acidificação. Observou-se variação considerável entre o Streptococcus thermophilus para a taxa máxima de acidificação $(\mathrm{Vm})$, com um máximo de -4,5 e mínimo de -4,2 pH miliunidades $\mathrm{min}^{-1}$. Os Lactobacillus delbrueickii subespécie bulgaricus apresentaram valores entre $-8,4$ e $-7,1 \mathrm{pH}$ miliunidades $\mathrm{min}^{-1}$. Estes resultados sugerem que as cepas caracterizadas com elevada capacidade de acidificação poderiam ser utilizadas como bactérias iniciadoras (starters) na fabricação de queijos. Os fermentos apresentaram excelente desempenho no processo de acidificação, gerando curvas adequadas, características de uma cultura iniciadora.

Palavras-chave: Bactérias nativas; Streptococcus; Lactobacillus.

\section{Introduction}

The lactic acid bacteria (LAB) are easily found as autochthonous microflora in raw milk (Rodríguez et al., 2000). In the current industrial food production, LAB are mostly focused on six genus and/or species: Lactococcus, Lactobacillus, Leuconostoc, Pediococcus, Oenococcus oeni and Streptococcus salivarius subspecie thermophiles (Klaenhammer et al., 2002; Ray \& Bhunia, 2014). Streptococcus thermophilus (S. thermophilus) adapts to the milky environment and can be isolated only from the milk. The amount of this microorganism in raw milk is small. Incubation at temperatures $>40{ }^{\circ} \mathrm{C}$ presents as an exclusive and selective means to enrich $S$. thermophilus from a mixed population (Harnett et al., 2011). Lactobacillus bacteria are not present after the milk has been milked aseptically, but the contamination may occur from contact with soil, manure, grass, silage or other foods adhered to the udder, as well as milking and milk storage equipment (De Angelis \& Gobbetti, 2011). There is a great demand for recovering microorganisms' starters from wild LABs of milk or raw dairy products (Wouters et al., 2002). Thermophilic LAB such as S. thermophilus, Lactobacillus helveticus and Lactobacillus delbrueickii subspecies bulgaricus or subspecie lactis (L. delb. subsp. bulgaricus or lactis) have long been used as starter cultures in the production of fermented milks and various Swiss and Italian cheeses (Iyer et al., 2010; Rizzello \& De Angelis, 2011). Since the intrinsic bacteria promote slow acidification, the function of the starter cultures is to accelerate the process and their addition maintains the uniformity of the products; however, the biota of the raw milk can be lost (Wouters et al., 2002). Rather than acidifying milk, LABs have the function of altering the flavor and texture properties of cheeses and inhibiting the development of pathogens and deteriorants (Leroy \& De Vuyst, 2004; Lahtinen et al., 2012). The acidification rate during the fermentation period can be described from the $\mathrm{pH}$ curves and the following kinetic parameters are calculated by: the maximum acidification rate $\left(\mathrm{V}_{\mathrm{m}}=\mathrm{dpH} / \mathrm{dt}\right)$, expressed as $\mathrm{pH}$ milliunits min $^{-1}$, which is the maximum slope of the acidification curve; and the time $\left(\mathrm{T}_{\mathrm{m}}\right)$, expressed as minutes, at which $\mathrm{V}_{\mathrm{m}}$ occurred (Zanatta \& Basso, 1992). These parameters have been widely studied (Kristo et al., 2013; Lucas et al., 2004; Chammas et al., 2006; Almeida et al., 2008; Damin et al., 2008). The S. thermophilus and Lactobacillus species have been used for centuries in the elaboration of fermented food and are considered Generally Recognized as Safe (GRAS) (Iyer et al., 2010; Gharaei-Fathabad \& Eslamifar, 2011). The use of the selected strains are important biological and genetic resources, and could assure cheese quality and typicality, and help protect the traditional process of fermented products. The southwest Parana region, Brazil, has been increasing its milk production in the lasts years, and, considering the main dairy regions of the state, was the region that showed the greatest growth in herd size and milk production between 2008 and 2013. During this period, production doubled, making it the leading dairy region of the state. Thus, actions that can contribute to the development and enhancement of the dairy chain are important and should be considered. 
This work aimed to isolate, identify, characterize and select the thermophilic lactic microflora of raw cow's milk obtained from Southwest Parana-Brazil, in order to clarify the potential technological role of S. thermophilus and L. delb. subsp. bulgaricus as autochthonous starter cultures.

\section{Material and methods}

\subsection{Strains and growth conditions}

Twenty milk samples were aseptically collected from bulk tanks in dairy farms and dairies in southwest Paraná - Brazil and transported to the laboratory under refrigerated conditions. These samples were subjected to heat treatment at $63{ }^{\circ} \mathrm{C}$ for $12 \mathrm{~min}$ and then incubated at $44{ }^{\circ} \mathrm{C}$ for approximately $12 \mathrm{~h}$ (acidity between 0.225 to 0.270 lactic acid $100 \mathrm{~mL}^{-1}$ ). The Streptococcus strains were grown in M17 Agar Base (HIMEDIA): $44{ }^{\circ} \mathrm{C}$ for $48 \mathrm{~h}$ and the Lactobacillus in Man, Rogosa \& Sharpe (MRS) medium (HIMEDIA): $\mathrm{pH} 5.45,44^{\circ} \mathrm{C}$ for $72 \mathrm{~h}$ (International Organization for Standardization, 2003). The morphology, Gram stain and catalase activity were also checked (Silva et al., 2010). The Enterococci were counted on Kanamycin Aesculin Azide Agar (KAA, Oxoid) after $24 \mathrm{~h}$ at $37^{\circ} \mathrm{C}$ under aerobic conditions (Baylis, 2007). For each culture, 10-12 colonies identified as $S$. thermophillus and Lactobacillus strain were purified by streaking onto M17 and MRS agars, respectively. The cultures were maintained at $-40{ }^{\circ} \mathrm{C}$ in $0.25 \mathrm{~mL}$ of M17 or MRS broths, supplemented with freezing mix (20 mM MgSO4 and 80\% glycerol) and $0.5 \mathrm{~mL}$ of reconstituted powdered milk, denominated the Stock Culture 1 (SC1), and numbered from S01 to S150 for Streptococcus, and from L01 to L141 for Lactobacillus species. Subsequently the colonies were slightly thawed and, with the help of disposable loops $(1 \mu \mathrm{L})$, were inserted into microtubes containing their respective solidified culture media (M17 and, MRS acidified at $\mathrm{pH} 5.45$ ). The tubes were then incubated at $44{ }^{\circ} \mathrm{C}$ in aerobiosis (Streptococcus) and anaerobiosis (Lactobacillus) until growth. The strains were conditioned in boxes with support for microtubes and sent to the BIOAGRO INSTITUTE (Thiene, Italy) for DNA extraction.

\subsection{DNA extraction, RAPD-PCR, species-specific pcr and analysis sequencing of the 16S ribosomal RNA}

In all, 58 Streptococcus and 48 Lactobacillus strains were revitalized by streaking (M17: $44{ }^{\circ} \mathrm{C}$ for $48 \mathrm{~h}$ and MRS: $37^{\circ} \mathrm{C}$ for $72 \mathrm{~h}$ ). Each strain was inoculated into $10 \mathrm{~mL}$ of the respective broth and incubated overnight. The cells were pelleted by centrifugation at $13.200 \mathrm{rpm}$ for $5 \mathrm{~min}$, the supernatant discarded, and the cell mass prepared for freezing according to the same procedure described for $\mathrm{SC} 1$, and stored at $-80{ }^{\circ} \mathrm{C}$, Stock Culture 2 (SC2). The isolates (SC2) were grown overnight at $37^{\circ} \mathrm{C}$ or $44^{\circ} \mathrm{C}$ in $10 \mathrm{~mL}$ of M17 or MRS broths, and the DNA extracted using the MicroLYSIS kit (Labogen, Italy) following the manufacturer's instructions. RAPD-PCR reactions were carried out with the primer D11344 (5' AGT GAA TTC GCG GTC AGA TGC CA3'). The following amplification conditions were used: an initial step of $94{ }^{\circ} \mathrm{C}$ for 2 min, followed by 35 cycles of $94{ }^{\circ} \mathrm{C}$ for $1 \mathrm{~min}, 42{ }^{\circ} \mathrm{C}$ for $1 \mathrm{~min}, 72{ }^{\circ} \mathrm{C}$ for $1.5 \mathrm{~min}$, and a final step at $72{ }^{\circ} \mathrm{C}$ for $10 \mathrm{~min}$ (Akopyanz et al., 1992). The amplification products were separated by electrophoresis on $1.5 \%(\mathrm{w} / \mathrm{v})$ agarose gels in $0.5 \%$ TBE buffer (54 $\mathrm{g}$ of Tris, $27.5 \mathrm{~g}$ of boric acid and $20 \mathrm{~mL}$ of $0.5 \mathrm{M}$ EDTA at pH 8.0). Grouping of the RAPD-PCR profiles was obtained using the Gel Compar 4.1 software package (Applied Maths, Kortrijk-Belgium) with the Pearson product moment correlation coefficient, and the Unweighted Pair Group Method with the Arithmetic Average (UPGMA) clustering algorithm (Vauterin \& Vauterin, 1992). Assignments to the species S. thermophilus and Streptococcus macedonicus (S. macedonicus) were confirmed for some strains by a species-specific PCR based on the amplification. The reactions were carried out with primers for $S$. Thermophilus (ST1: CAC TAT GCT CAG AAT ACA; ST2: CGA ACA GCA TTG ATG TTA) and 30-cycle amplification conditions as follows: $90{ }^{\circ} \mathrm{C}$ for $30 \mathrm{~s}, 54{ }^{\circ} \mathrm{C}$ for $70 \mathrm{~s}$ and $70{ }^{\circ} \mathrm{C}$ for $30 \mathrm{~s}$ according to Lick et al. (1996), and for S. macedonicus (MAC1: ACT GCG CTG TGG GAA GTC; 
MAC2: CCT TCT CCC GAA GTT ACG) with the following amplification conditions: $94{ }^{\circ} \mathrm{C}$ for 3 min and 30 cycles: $94^{\circ} \mathrm{C}$ for $1 \mathrm{~min}, 58^{\circ} \mathrm{C}$ for $1 \mathrm{~min}$ and $72{ }^{\circ} \mathrm{C}$ for $1 \mathrm{~min}$ (Lombardi et al., 2004). The DNA sequences were thus obtained (Klijn et al., 1991). The following strains were used as references in the genetic assays: S. macedonicus $893^{\mathrm{T}}$ and $S$. thermophilus $85^{\mathrm{T}}$, for L. delb. subsp. bulgaricus $92^{\mathrm{T}}$, L. delb. subsp. lactis $137^{\mathrm{T}}$ and L. helveticus $303^{\mathrm{T}}$.

\subsection{Acidification rate}

The acidification kinetics was evaluated in the Micros automatic system for $\mathrm{pH}$ measurement and data acquisition (Conegliano, Italy). One hundred microliters of an overnight culture in M17 or MRS broths were inoculated into $10 \mathrm{~mL}$ of reconstituted skim milk and incubated at $37{ }^{\circ} \mathrm{C}$ until coagulation. Two milliliters were then inoculated into $250 \mathrm{~mL}$ glass bottles containing $200 \mathrm{~mL}$ of reconstituted skim milk and incubated at $37{ }^{\circ} \mathrm{C}$ (S. thermophilus) or $44{ }^{\circ} \mathrm{C}$ (L. delb. subsp. bulgaricus) for $16 \mathrm{~h}$. The $\mathrm{pH}$ was measured continuously by introducing the electrodes, disinfected with ethanol, through holes in the screw cap, together with the Micros integrated data acquisition system (Conegliano, Italy), (Zanatta \& Basso, 1992). A control culture (S439C) was also used to determine the acidification rate for S. thermophilus.

\section{Results and discussion}

\subsection{Identification of the isolates}

The bacterial isolates were subjected to Gram staining and to the catalase test, and identified as Gram-positive and catalase-negative bacilli or cocci. Enterococci are the microorganisms that inhabit the ecosystem of raw milk, but were not found in the samples under examination. Their presence could cause confusion in the identification of the LAB bacteria of interest. To selectively enumerate enterococci as unique components, the culture medium used is Kanamycin-aesculin-azide (KAA). Enterococci are commonly observed in association with a diverse microflora, so any other members of the LAB make it difficult to examine a mixed microflora (Domig et al., 2003), since they may survive low pasteurization temperatures (Giraffa, 2003).

\subsection{Identification of Streptococcus and Lactobacillus species}

The numerical elaboration of the combined RAPD-PCR profiles of the 58 natural isolates and the two type/reference strains $\left(85^{\mathrm{T}}\right.$ for $S$. thermophilus and $893^{\mathrm{T}}$ for $S$. macedonicus) clustered by the UPGMA analysis, resulted in the dendrogram shown in Figure 1. 


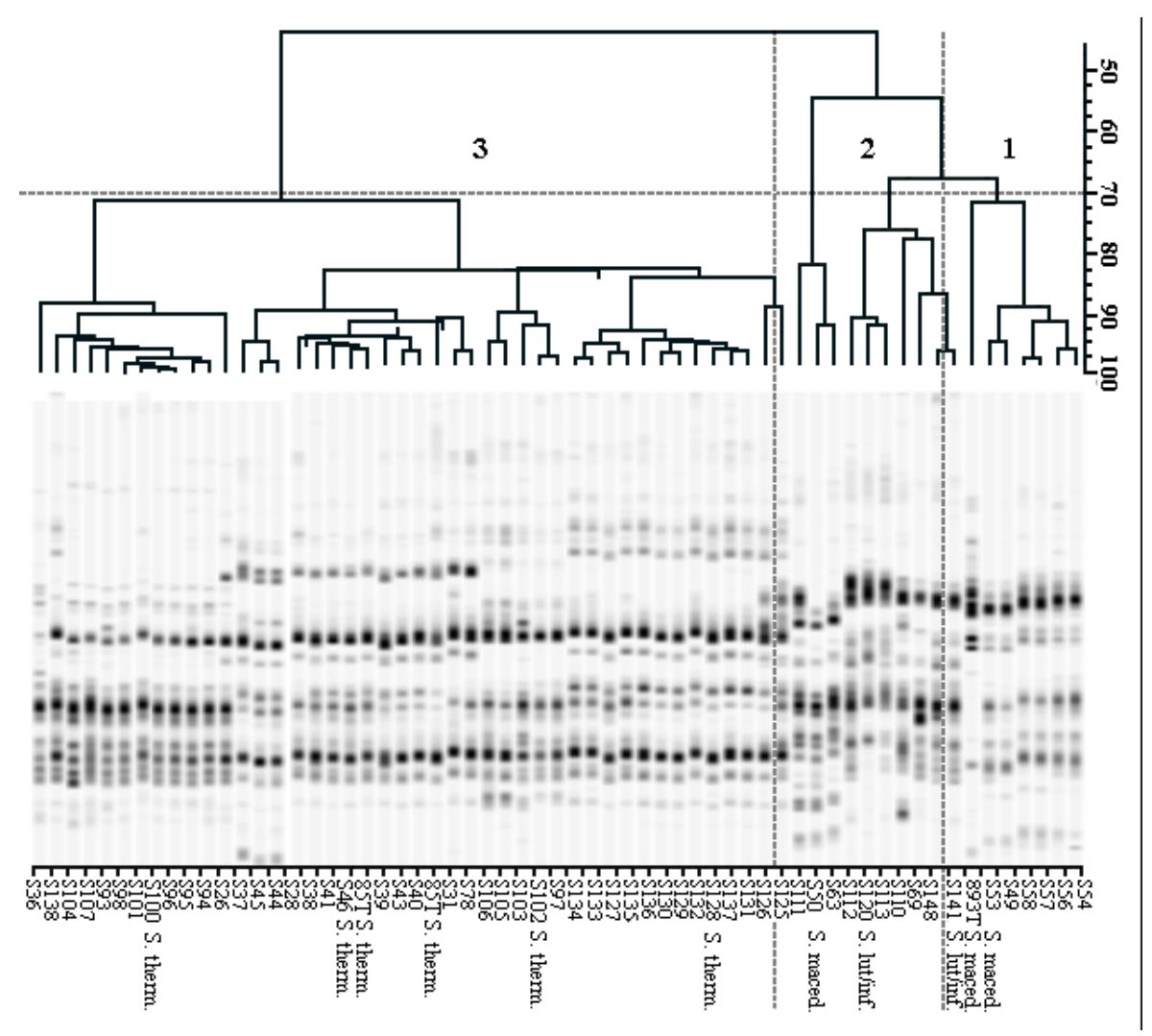

Figure 1. Cluster analysis of the RAPD-PCR profiles of Streptococcus type/reference strain isolates originating from raw milk.

We observed genotypic heterogeneity among the isolated strains, confirmed by the low coefficient of similarity (64\%), and three clusters (labelled 1 to 3 ). Strains $\geq 90 \%$ of similarity coefficient can be classified as being extremely close genotypically, and perhaps even identical (Morandi \& Brasca, 2012). Cluster 1 comprised the $S$. macedonicus strain, with six isolates, while cluster 2 contained the Streptococcus lutetiensis/infantarius type strain. Finally, most of the isolates (41 of 58) were grouped in cluster 3 , with the strain type of $S$. thermophillus. A species-specific PCR analysis of a number of isolates (Figure 1) confirmed the assignment of the isolates included in cluster 1 as the species $S$. macedonicus (S53); also the assignment of strain S50 (cluster 2) was confirmed as this strain, and cluster 3 as S. thermophillus (S46, S100, S102 and S128). The strains S36, S63 and S111 did not belong to any of the types/references considered in this work. The strains, S120 and S141, in cluster 2 were confirmed by genetic sequencing as S. lutetiensis/infantarius, and $70.7 \%$ of the isolates obtained from the raw milk were identified as $S$. thermophilus. This microorganism is largely found in natural milk and whey cultures used in the production of Italian cheeses of protected designation origin (PDO) and artisanal ones such as Asiago, Fontina, Gorgonzola, Grana Padano, Montasio, Monte Veronese, Mozzarella, Parmegiano Reggiano, Pecorino Toscano, Provolone and Taleggio cheeses (Coppola et al., 1998; Bizzarro et al., 2000; Beresford et al., 2001; Giraffa et al., 2001; Andrighetto et al., 2002; Marino et al., 2003; Dolci et al., 2009; Lazzi et al., 2009). S. thermophilus isolates represented the majority in both the pasteurized milk $\left(63{ }^{\circ} \mathrm{C}\right.$ for $30 \mathrm{~min}$ ) samples and the pasteurized milk samples incubated at $42{ }^{\circ} \mathrm{C}$ for $24 \mathrm{~h}$, followed by L. delb. subsp. bulgaricus and S. macedonicus (Almeida et al., 2009). S. macedonicus, which was first isolated from Greek Kasseri cheese, has been described in Italian cheeses. Given that most of the isolates studied originated from raw milk cheeses, the authors of this paper speculated that this organism could arise from the raw milk (Tsakalidou et al., 1998; Andrighetto et al., 2002; Gatto et al., 2002). The use of $S$. macedonicus is more efficient as primary culture rather than adjunct starter (Lombardi et al., 2004; Anastasiou et al., 2007) is of interest, and also that it has multifunctional properties 
which could be exploited by the food industry, such as peptidase activity (Georgalaki et al., 2000) and the production of exopolysaccharides (Vincent et al., 2001). Streptococcus infantarius subsp. infantarius has been found in the world in fermented food products, mainly after spontaneous fermentation, and is a member of the Streptococcus bovis and equinus complex (SBSEC) which is associated with several human infections (Schlegel et al., 2000; Herrera et al., 2009; Boleij et al., 2011; Schlegel et al., 2003). The type and microbial load is influenced by milk composition, associated with the conditions of raw milk production, mainly related to the hygienic practices during milking, can determine the presence of deteriorating, pathogenic or useful cheesemaking bacteria (Schlegel et al., 2003). The numerical elaboration of the combined RAPD-PCR profiles of the 48 natural isolates and the three type/reference strains (92T for L. delb. subsp. bulgaricus, $137 \mathrm{~T}$ for L. delb. subsp. lactis and 303T for L. helveticus) clustered by the UPGMA analysis, resulted in the dendrogram shown in Figure 2.

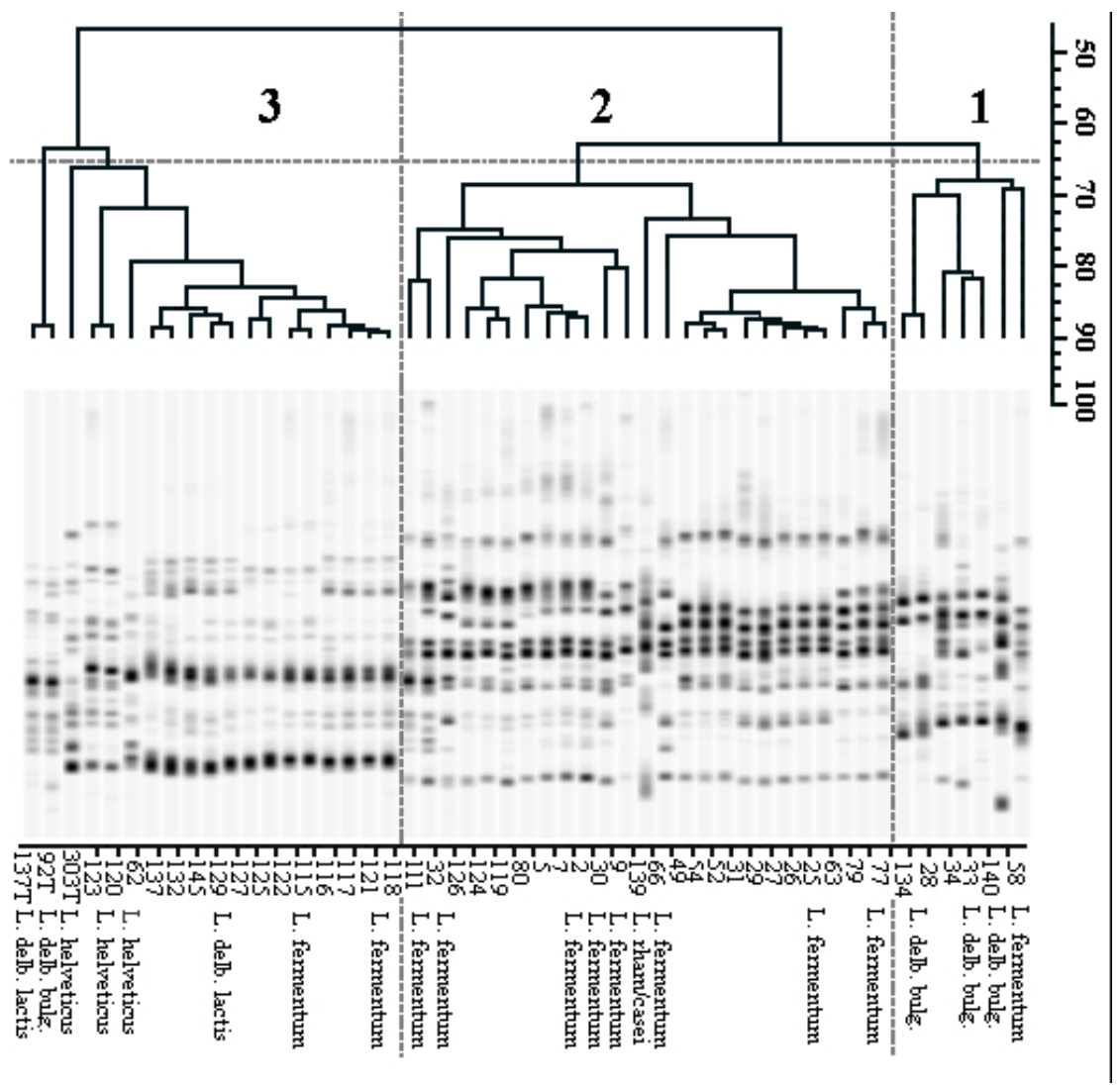

Figure 2. Cluster analysis of the RAPD-PCR profiles of the Lactobacillus type/reference strain isolates originating from raw milk.

At a similarity level of $65 \%$, arbitrarily chosen to define the species, three phenotypic clusters were differentiated amongst the lactobacilli (labelled 1 to 3 ) and four independent strains were detected by genetic sequencing: L. fermentum, L. delb. subsp. bulgaricus, L. rhamonus/casei and L. helveticus. Of the 16 strains subjected to the gene sequencing analysis, 10 were confirmed as L. fermentum $(62.5 \%), 03$ as L. delb. subsp. bulgaricus (18.75\%), 2 as L. helveticus (12.5\%) and 1 as L. rhamnosus/casei (6.25\%). The results indicated the prevalence of the L. fermentum strains, species characterized by a heterofermentative metabolism (Kostinek et al., 2008; Akabanda et al., 2013). In a study of Lactobacilli isolated from raw cow and buffalo milks, $48 \%$ of the strains identified were L. fermentum followed by $34 \%$ L. acidophilus, $8 \%$ L. viridescens, $5 \%$ L. brevis and 4\% L. gasseri (4\%), (Mithun et al., 2015). In another study carried out with strains isolated from raw cow milk, the dominant species were L. xylosus $(86.7 \%)$ and L. casei subsp. pseudoplantarum 
(13.3\%) (Abdullah \& Osman, 2010). The diversity of the lactobacilli present in milk indicates a variation of the species according to area, caused mainly by differences in climate, vegetation and feed supplied to the animals.

Our results indicated that Streptococcus thermophilus and Lactobacillus fermentum were predominant. In recent research about microbial diversity in Brazilian artisanal cheeses (made with raw milk), the predominate genera were of Streptococcus, Leuconostoc and Lactococcus (Kamimura et al., 2019). The occurrence of one or other BALs type may be related to the origin of the raw material, if were isolated from raw milk, pasteurized and/or from the cheese and in this case the maturation time may influence in the microbiota.

\subsection{Acidifying activity of lactic bacteria}

Cultures Starters can be defined as preparations containing microorganisms that are developed by the fermentation of a certain substrate, such as lactose, present in the medium and its transformation into lactic acid, in the initial stage of the production of fermented milks and cheeses. A useful rule is to decrease the value to $<5.3$ in the milk in approximately $6 \mathrm{~h}$ at $30^{\circ} \mathrm{C}$ to $37^{\circ} \mathrm{C}$, depending on the dairy product. The low $\mathrm{pH}$ inhibits undesirable organisms, and, in fermented milks, promotes the formation of the gel. Starters may also impart other benefits for health (Beresford et al., 2001; De Angelis \& Gobbetti, 2011; Harnett et al., 2011). Thus, for the production of starters, it is important that the strains exhibit high fermentation rates in order to ensure that the $\mathrm{pH}$ values of the cheeses reach a value close to 5.2 in less than 6 hours. Strains of $S$. thermophilus and L. delb. subsp. bulgaricus were selected to verify the acidification rate and the results of the analysis can be seen in Table 1 .

Table 1. Kinetic parameters of the strains of $S$. thermophilus and L delbrueckii subsp. Bulgaricus.

\begin{tabular}{|c|c|c|c|c|}
\hline Strain & Isolate code & $V_{m} d p H d t^{-1 a}$ & $T_{\max }(\min )^{b}$ & $\mathbf{T}_{\mathrm{pH} 5,2^{\mathrm{c}}}$ \\
\hline \multirow{16}{*}{ S. thermophilus } & S439C & -14.5 & 185 & 222 \\
\hline & $\mathrm{S} 128$ & -12.8 & 206 & 277 \\
\hline & S28 & -14.5 & 152 & 226 \\
\hline & S104 & -13.1 & 209 & 255 \\
\hline & $\mathrm{S} 100$ & -14.2 & 212 & 261 \\
\hline & S103 & -13.0 & 224 & 272 \\
\hline & S93 & -13.8 & 211 & 267 \\
\hline & S102 & -12.1 & 196 & 284 \\
\hline & $\mathrm{S} 125$ & -7.2 & 396 & 526 \\
\hline & S63 & -5.0 & 391 & $\ldots$ \\
\hline & S111 & -5.3 & 384 & $\ldots$. \\
\hline & S141 & -5.1 & 418 & $\ldots$. \\
\hline & $\mathrm{S} 46$ & -6.5 & 382 & $\ldots$. \\
\hline & $\mathrm{S} 43$ & -6.2 & 159 & $\ldots$. \\
\hline & $\mathrm{S} 50$ & -5.4 & 649 & $\ldots$. \\
\hline & S53 & -4.2 & 532 & $\ldots$ \\
\hline \multirow{6}{*}{$\begin{array}{l}\text { L. delbrueckii subsp. } \\
\text { bulgaricus }\end{array}$} & LB120 & -13.7 & 563 & 579 \\
\hline & LB140 & -8.4 & 242 & 329 \\
\hline & LB34 & -8.4 & 263 & 301 \\
\hline & LB134 & -8.0 & 302 & 356 \\
\hline & LB33 & -7.7 & 256 & 330 \\
\hline & LB28 & -7.1 & 242 & 326 \\
\hline
\end{tabular}

${ }^{\mathrm{a}} \mathrm{V}_{\mathrm{m}}$, corresponds to the maximum slope of the acidification curve and represents the maximum acidification rate ( $\mathrm{pH}$ milliunits min ${ }^{-1}$ ). ${ }^{\mathrm{b}}$ Time at which the maximum acidification rate $\left(\mathrm{V}_{\mathrm{m}}\right)$ occurred. ${ }^{\mathrm{c}}$ Time at which the $\mathrm{pH}$ reached 5.2. ${ }^{\mathrm{d}} \mathrm{Control}$ culture.

The maximum acidification rates $\left(\mathrm{V}_{\mathrm{m}}\right)$ of the $S$. thermophilus and L. delb. subsp. bulgaricus isolates, the times $(\mathrm{Tm})$ required for the different strains to reach the $\mathrm{V}_{\mathrm{m}}$ values, and the time taken to reach $\mathrm{pH} 5.2$ can 
be seen in Table 1. S. thermophilus strains are defined as "fast acidifiers" and show a mean $\mathrm{V}_{\mathrm{m}}$ value of $-10.73 \mathrm{pH}$ milliunits $\mathrm{min}^{-1}$ (Zanatta \& Basso, 1992), but $46.67 \%$ of the isolates examined in this study showed $\mathrm{V}_{\mathrm{m}}$ values below this reference. The $\mathrm{V}_{\mathrm{m}}$ values ranged between -8.4 and $-7.1 \mathrm{pH}$ milliunits $\min ^{-1}$ in the six samples of $L$. delb. subsp. bulgaricus studied. A study of these pure cultures isolated from fermented milks and known as "laban", showed maximum acidification rates of $-10.5 \mathrm{pH}$ milliunits $\mathrm{min}^{-1}$ (Chammas et al., 2006). The symbiotic relationship between $S$. thermophilus and $L$. delb. subsp. bulgaricus has long been used in the manufacture of fermented milks and various cheeses. Co-cultures achieve higher $\mathrm{V}_{\mathrm{m}}$ values, typical of fast strains. with reported $\mathrm{Vm}$ values of -14.5 and $-13.75 \mathrm{pH}$ milliunits $\mathrm{min}^{-1}$ (Oliveira \& Damin, 2003; Almeida et al., 2009), respectively. The S. thermophilus strains S28, S104 and S128 showed acidifying activity with a reduction in $\mathrm{pH}$ to about 5.2 in similar period time to that of the standard (222 $\mathrm{min}$.), and the L. delb. subsp. bulgaricus strains all showed similar acidification times with a minimum value of $301 \mathrm{~min}$ for L34 and maximum value of 356 min for L134.

Two yeasts, A and B, were developed with best strains. The yeast A composed of strains S28 and S128 (S. thermophillus) and strain LB134 (L. delbrueckii sp. bulgaricus), and B composed of strains S98 and S104 (S. thermophillus) and a strain LB134 (L. delbrueckii sp. bulgaricus). The acidity of fermentation was evaluated during the preparation of the Santo Giorno cheese typical of Southwestern region of Parana - Brazil, according to the methodology described by Pereira et al. (2017), the results of which are showed in Figure 3.

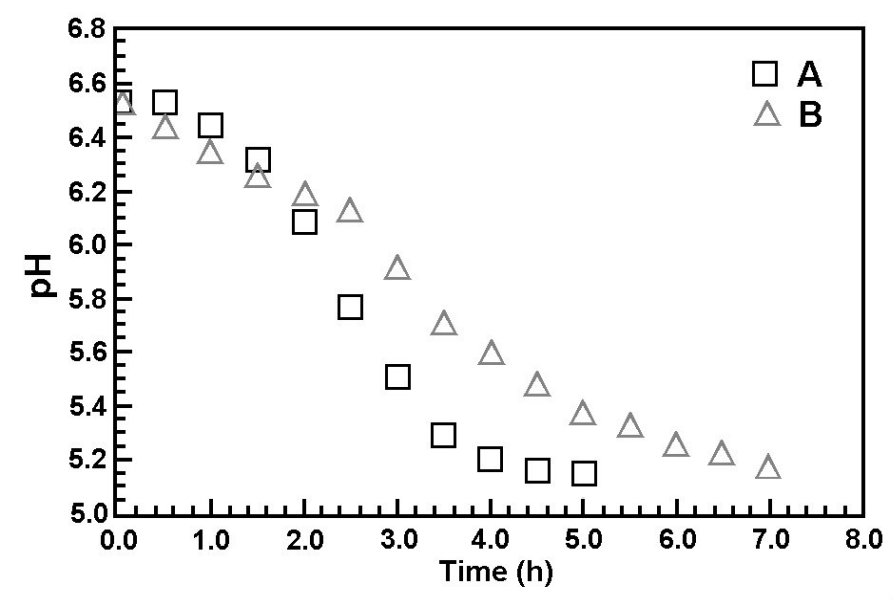

Figure 3. Average acidification curve of ferments A and B.

We observed that the ferments presented an excellent performance in the acidification process, generating adequate curves, characteristics of a starter culture. The average $\mathrm{pH}$ of the dough was reduced to a value of about 5.20 in a maximum time of 4 hours for yeast A and 7 hours for yeast B.

\section{Conclusions}

The results indicate that cow's milk obtained from Southwest Paraná, Brazil, exhibits a wide diversity of thermophilic LAB (S. thermophilus, S. macedonicus, S. lutetiensis/infantarius, L. helveticus, L. fermentum, L. delb. sups. bulgaricus, L. rham/casei), where their separation into clusters can define distinct groups of strains. Such information is essential and fosters evidence that natural environments are rich in biodiversity and carrying sources of strains and species, as example LAB group. S. thermophilus and L. fermentum are predominant in the milk analyzed and may play an important role in their quality. The acidification rates suggest that the strains S128, S28, S104, S100, S103, S93, S102, L140, L34, L134, L33 and L28 have 
potential as autochthonous starter cultures in cheese manufacture. A well characterized bacterial culture can serve as the source for the construction of a starter with well-defined functional properties.

\section{Acknowledgements}

The authors thank the Parana Southwest Regional Development Agency, UTFPR - Campus PB, FB e DV, the Association of Municipalities in Southwest Parana (AMSOP), SEBRAE, the Association of Belluno Emigrants, the Regional Government of Veneto - Italy, the Coordination for the Improvement of Higher Education Personnel (CAPES), BIOAGRO-Italy, the Mezzomo Family, Angiolella Lombardi, Battista Attorni and Giuseppe Pellegrini.

\section{References}

Abdullah, A. S., \& Osman, M. M. (2010). Isolation and identification of lactic acid bacteria from raw cow milk, white cheese and rob in Sudan. Pakistan Journal of Nutrition, 9(12), 1203-1206. http://dx.doi.org/10.3923/pjn.2010.1203.1206

Akabanda, F., Owusu-Kwarteng, J., Tano-Debrah, K., Glover, R. L., Nielsen, D. S., \& Jespersen, L. (2013). Taxonomic and molecular characterization of lactic acid bacteria and yeasts in nunu, a Ghanaian fermented milk product. Food Microbiology, 34(2), 277-283. PMid:23541194. http://dx.doi.org/10.1016/j.fm.2012.09.025

Akopyanz, N., Bukanov, N. O., Westblom, T. U., Kresovich, S., \& Berg, D. E. (1992). DNA diversity among clinical isolates of Helicobacter pylori detected by PCR-based RAPD fingerprinting. Nucleic Acids Research, 20(19), 5137-5142. PMid:1408828. http://dx.doi.org/10.1093/nar/20.19.5137

Almeida, K. E., Tamime, A. Y., \& Oliveira, M. N. (2008). Acidification rates of probiotic bactéria in Minas frescal cheese whey. Lebensmittel-Wissenschaft + Technologie, 41(2), 311-316. http://dx.doi.org/10.1016/j.Iwt.2007.02.021

Almeida, K. E., Tamime, A. Y., \& Oliveira, M. N. (2009). Influence of total solids contents of milk whey on the acidifying profile and viability of various lactic acid bacteria. Lebensmittel-Wissenschaft + Technologie, 42(2), 672-678. http://dx.doi.org/10.1016/j.lwt.2008.03.013

Anastasiou, R., Georgalaki, M., Manolopoulou, E., Kandarakis, I., De Vuyst, L., \& Tsakalidou, E. (2007). The performance of Streptococcus macedonicus ACA-DC 198 as starterculture in Kasseri cheese production. International Dairy Journal, 17(3), 208-217. http://dx.doi.org/10.1016/j.idairyj.2006.02.011

Andrighetto, C., Borney, F., Barmaz, A., Stefanon, B., \& Lombardi, A. (2002). Genetic diversity of Streptococcus thermophilus strains isolated from Italian traditional cheeses. International Dairy Journal, 12(2-3), 141-144. http://dx.doi.org/10.1016/S09586946(01)00134-0

Baylis, C. L. (2007). Manual of microbiological methods for the food and drink industry (5th ed.). Chipping Campden: Campden \& Chorleywood Food Research Association.

Beresford, T. P., Fitzsimons, N. A., Brennan, N. L., \& Cogan, T. (2001). Recent advances in cheese microbiology. International Dairy Journal, 11(4-7), 259-274. http://dx.doi.org/10.1016/S0958-6946(01)00056-5

Bizzarro, R., Torri, T. G., Giraffa, G., \& Neviani, E. (2000). Phenotypic and genotypic characterization of lactic acid bacteria isolated from Pecorino Toscano cheese. Italian Journal of Food Science, 12, 303-316.

Boleij, A., Muytjens, C. M. J., Bukhari, S. I., Cayet, N., Glaser, P., Hermans, P. W. M., Swinkels, D. W., Bolhuis, A., \& Tjalsma, H. (2011). Novel clues on the specific association of Streptococcus gallolyticus subsp. gallolyticus with colorectal cancer. The Journal of Infectious Diseases, 203(8), 1101-1109. PMid:21451000. http://dx.doi.org/10.1093/infdis/jiq169

Chammas, G. I., Saliba, R., Corrieu, G., \& Béal, C. (2006). Characterisation of lacticacid bacteria isolated from fermented milk "laban". International Journal of Food Microbiology, 110(1), 52-61. PMid:16701913.

http://dx.doi.org/10.1016/j.jifoodmicro.2006.01.043

Coppola, S., Parente, E., Dumontet, S., \& La Peccerella, A. (1998). The microflora of natural whey cultures utilized as starters in the manufacture of Mozzarella cheese from waterebuffalo milk. Le Lait, 68(3), 295-310. http://dx.doi.org/10.1051/lait:1988319

Damin, M. R., Minowa, E., Alcântara, M. R., \& Oliveira, M. N. (2008). Effect of cold storage on culture viability and some rheological properties of fermented milk prepared with yogurt and probiotic bacteria. Journal of Texture Studies, 39(1), 40-55. http://dx.doi.org/10.1111/j.1745-4603.2007.00129.x

De Angelis, M., \& Gobbetti, M. (2011). Lactobacillus spp.: General characteristics. In J. Fuquay, P. Fox \& P. McSweeney (Eds.), Encyclopedia of dairy science (pp. 78-90). San Diego: Academic Press, Elsevier Science. http://dx.doi.org/10.1016/B978-0-12374407-4.00259-4.

Dolci, P., Barmaz, A., Zenato, S., Pramotton, R., Alessandria, V., Cocolin, L., Rantsiou, K., \& Ambrosoli, R. (2009). Maturing dynamics of surface microflora in Fontina PDO cheese studied by culture dependent and independent methods. Journal of Applied Microbiology, 106(1), 278-287. PMid:19054234. http://dx.doi.org/10.1111/j.1365-2672.2008.04001.x

Domig, K. J., Mayer, H. K., \& Kneifel, W. (2003). Methods used for the isolation, enumeration, characterization and identification of Enterococcus spp. 1. Media for isolation and enumeration. International Journal of Food Microbiology, 88(2-3), 147-164. PMid:14596987. http://dx.doi.org/10.1016/S0168-1605(03)00177-6 
Beux, S. et al.

Gatto, V., Rizzotti, L., \& Torriani, S. (2002). Genetic diversity of lactic acid bacteria strains from Ragusano cheese as evaluated by RAPD-PCR. L'Industria del Latte, 38, 65-68.

Georgalaki, M. D., Sarantinopoulos, P., Ferreira, E. S., De Vuyst, L., Kalantzopoulos, G., \& Tsakalidou, E. (2000). Biochemical properties of Streptococcus macedonicus strains isolated from Greek Kasseri cheese. Journal of Applied Microbiology, 88(5), 817-825. PMid:10792542. http://dx.doi.org/10.1046/j.1365-2672.2000.01055.x

Gharaei-Fathabad, E., \& Eslamifar, M. (2011). Isolation and applications o fone strain of Lacttobacillus paraplantarum from tea leaves (Camellia sinensis). American Journal of Food Technology, 6(5), 429-443. http://dx.doi.org/10.3923/ajft.2011.429.434

Giraffa, G. (2003). Functionality of enterococci in dairy products. International Journal of Food Microbiology, 88(2-3), 215-222. PMid:14596993. http://dx.doi.org/10.1016/S0168-1605(03)00183-1

Giraffa, G., Paris, A., Valcavi, L., Gatti, M., \& Neviani, E. (2001). Genotypic and phenotypic heterogeneity of Streptococcus thermophilus strains isolated from dairy products. Journal of Applied Microbiology, 91(5), 937-943. PMid:11722674. http://dx.doi.org/10.1046/j.1365-2672.2001.01464.x

Harnett, J., Davey, G., Patrick, A., Caddick, C., \& Pearce, L. (2011). Streptococcus thermophilus. In J. W. Fuquay, P. L. H. McSweeney \& P. F. Fox (Eds.), Encyclopedia of dairy sciences. San Diego: Academic Press.

Herrera, P., Kwon, Y. M., \& Ricke, S. C. (2009). Ecology and pathogenicity of gastrointestinal Streptococcus bovis. Anaerobe, 15(1-2), 44-54. PMid:19100852. http://dx.doi.org/10.1016/j.anaerobe.2008.11.003

International Organization for Standardization - ISO. (2003). ISO 7889:2003 (IDF 117:2003): Yoghurt: Enumeration of characteristic microorganisms: Colony-count technique at 37 degrees ${ }^{\circ} \mathrm{C}$. Geneva: ISO.

lyer, R., Tomar, S. K., Uma Maheswari, T., \& Singh, R. (2010). Streptococcus thermophilus strains: Multifunctional lactic acid bacteria. International Dairy Journal, 20(3), 133-141. http://dx.doi.org/10.1016/j.idairyj.2009.10.005

Kamimura, B. A., De Filippis, F., Sant'Ana, A. S., \& Ercolini, D. (2019). Large-scale mapping of microbial diversity in artisanal Brazilian cheeses. Food Microbiology, 80, 40-49. PMid:30704595. http://dx.doi.org/10.1016/j.fm.2018.12.014

Klaenhammer, T., Altermann, E., Arigoni, F., Bolotin, A., Breidt, F., Broadbent, J., Cano, R., Chaillou, S., Deutscher, J., Gasson, M., van de Guchte, M., Guzzo, J., Hartke, A., Hawkins, T., Hols, P., Hutkins, R., Kleerebezem, M., Kok, J., Kuipers, O., Lubbers, M., Maguin, E., McKay, L., Mills, D., Nauta, A., Overbeek, R., Pel, H., Pridmore, D., Saier, M., van Sinderen, D., Sorokin, A., Steele, J., O'Sullivan, D., de Vos, W., Weimer, B., Zagorec, M., \& Siezen, R. (2002). Discovering lactic acid bacteria by genomics. Antonie van Leeuwenhoek, 82(1-4), 29-58. PMid:12369195.

Klijn, N., Weerkamp, A. H., \& De Vos, W. M. (1991). Identification of mesophilic lactic acid bacteria by using polymerase chain reaction-amplified variable regions of $16 \mathrm{~S}$ rRNA and specific DNA probes. Applied and Environmental Microbiology, 57(11), 3390-3393. PMid:1723586. http://dx.doi.org/10.1128/AEM.57.11.3390-3393.1991

Kostinek, M., Ban-Koffi, L., Ottah-Atikpo, M., Teniola, D., Schillinger, U., Holzapfel, W. H., \& Franz, C. M. (2008). Diversity of predominant lactic acid bacteria associated with cocoa fermentation in Nigeria. Current Microbiology, 56(4), 306-314. PMid:18213481. http://dx.doi.org/10.1007/s00284-008-9097-9

Kristo, E., Biliaderis, C. G., \& Tzanetakis, N. (2013). Modeling of rheological, microbiological and acidification properties of a fermented milk produce containing a probiotic strain of Lactobacillus paracasei. International Dairy Journal, 13(7), 517-528. http://dx.doi.org/10.1016/S0958-6946(03)00074-8

Lahtinen, S., Ouwehand, A. C., Salminen, S., \& Von, W. A. (2012). Lactic acid bacteria: Microbial and functional aspects. Boca Raton: Taylor \& Francis Group LLC, CRC Press.

Lazzi, C., Bove, C. G., Sgarbi, E., Gatti, M., Gioia, F., Torrioni, S., \& Neviane, E. (2009). Application of AFLP fingerprint analysis for studying the biodiversity of Streptococcus thermophilus. Journal of Microbiological Methods, 79(1), 48-54. PMid:19647766. http://dx.doi.org/10.1016/j.mimet.2009.07.021

Leroy, F., \& De Vuyst, L. (2004). Lactic acid bacteria as functional starter cultures for the food fermentation industry. Trends in Food Science \& Technology, 15(2), 67-78. http://dx.doi.org/10.1016/j.tifs.2003.09.004

Lick, S., Keller, M., Bockelmann, W., \& Heller, K. J. (1996). Rapid identification of Streptococcus thermophilus by primer-specific PCR amplification based on its lacZ gene. Systematic and Applied Microbiology, 19(1), 74-77. http://dx.doi.org/10.1016/S07232020(96)80012-9

Lombardi, A., Gatti, M., Rizzotti, L., Torriani, S., Andrighetto, C. N., \& Giraffa, G. (2004). Characterization of Streptococcus macedonicus strains isolated from artisanal Italian raw milk cheeses. International Dairy Journal, 14(11), 967-976. http://dx.doi.org/10.1016/j.idairyj.2004.04.005

Lucas, A., Sodini, I., Monnet, C., Jolivet, P., \& Corrieu, G. (2004). Probiotic cell counts and acidification in fermented milks supplemented with milk protein hydrolysates. International Dairy Journal, 14(1), 47-53. http://dx.doi.org/10.1016/S09586946(03)00147-X

Marino, M., Maifreni, M., \& Rondinini, G. (2003). Microbiological characterization of artisanal Montasio cheese: Analysis of its indigenous lactic acid bacteria. FEMS Microbiology Letters, 229(1), 133-140. PMid:14659553. http://dx.doi.org/10.1016/S03781097(03)00816-4

Mithun, S., Dipak, V., \& Sheela, S. (2015). Isolation and Identification of lactobacilli from raw milk samples obtained from Aarey Milk Colony. International Journal of Scientific and Research Publications, 5, 1-5.

Morandi, S., \& Brasca, M. (2012). Safety aspects, gentic diverty and technological caracterization of wild-type Streptococcus thermophilus strains isolated from north Italy traditional cheeses. Food Control, 23(1), 203-209. http://dx.doi.org/10.1016/j.foodcont.2011.07.011 
Selection of raw cow's milk thermophilic lactic acid bacteria obtained from southwest Parana, Brazil, with potential use as autochthonous starter

Beux, S. et al.

Oliveira, M. N., \& Damin, M. R. (2003). Efeito do teor de sólidos e da concentração de sacarose na acidificação, firmeza e viabilidade de bactérias do iogurte e probióticas em leite fermentado. Ciência e Tecnologia dos Alimentos, 23, 172-176. http://dx.doi.org/10.1590/S0101-20612003000400032

Pereira, E. A., Roncatti, R., Todescatto, C., Beux, S., Marchi, J. F., \& Daltoé, M. L. M. (2017). Acceptance of santo giorno cheese typical of the southwestern region of paraná, Brazil. Ciência Rural, 47(4), 1-8. http://dx.doi.org/10.1590/0103$8478 \mathrm{cr} 20160418$

Ray, B., \& Bhunia, A. (2014). Fundamental food microbiology (5th ed.). Boca Raton: Taylor \& Francis Group LLC.

Rizzello, C. G., \& De Angelis, M. (2011). Lactobacillus spp.: Lactobacillus delbrueckii group. In J. W. Fuquay, P. L. H. McSweeney \& P. F. Fox (Eds.), Encyclopedia of dairy sciences (2nd ed., pp. 119-124). San Diego: Academic Press. http://dx.doi.org/10.1016/B978-0-12-374407-4.00264-8.

Rodríguez, E., González, B., Gaya, P., Nuñez, M., \& Medina, M. (2000). Diversity of bacteriocins produced by lactic acid bacteria isolated from raw milk. International Dairy Journal, 10(1-2), 7-15. http://dx.doi.org/10.1016/S0958-6946(00)00017-0

Schlegel, L., Grimont, F., Ageron, E., Grimont, P. A., \& Bouvet, A. (2003). Reappraisal of the taxonomy of the Streptococcus bovis/Streptococcus equinus complex and related species: Description of Streptococcus gallolyticus subsp. gallolyticus subsp. nov., S. gallolyticus subsp. macedonicus subsp. nov. and S. gallolyticus subsp. pasteurianus subsp. nov. International Journal of Systematic and Evolutionary Microbiology, 53(Pt 3), 631-645. PMid:12807180. http://dx.doi.org/10.1099/ijs.0.02361-0

Schlegel, L., Grimont, F., Collins, M. D., Régnault, B., Grimont, P. A., \& Bouvet, A. (2000). Streptococcus infantarius sp. nov., Streptococcus infantarius subsp. infantarius subsp. nov. and Streptococcus infantarius subsp. coli subsp. nov., isolated from humans and food. International Journal of Systematic and Evolutionary Microbiology, 50(Pt 4), 1425-1434. PMid:10939646. http://dx.doi.org/10.1099/00207713-50-4-1425

Silva, N., Junqueira, V. C. A., \& Silveira, N. S. A. (2010). Manual de métodos de análise microbiológica de alimentos e água (4. ed.). São Paulo: Varela.

Tsakalidou, E., Zoidou, E., Pot, B., Wassill, L., Ludwig, W., Devriese, L. A., Kalantzopoulos, G., Schleifer, K. H., \& Kersters, K. (1998). Identification of streptococci from Greek Kasseri cheese and description of Streptococcus macedonicus sp. nov. International Journal of Systematic Bacteriology, 48(Pt 2), 519-527. PMid:9731293. http://dx.doi.org/10.1099/00207713-48-2519

Vauterin, L., \& Vauterin, P. (1992). Computer-aided objective comparison of electrophoresis patterns for grouping and identification of microorganisms. European Microbiology, 1, 37-41.

Vincent, S. J. F., Faber, E. J., Neeser, J. R., Stingele, F., \& Kamerling, J. P. (2001). Structure and properties of the exopolysaccharide produced by Streptococcus macedonicus. Glycobiology, 11(2), 131-139. PMid:11287400. http://dx.doi.org/10.1093/glycob/11.2.131

Wouters, J. A., Ayad, E. H. E., Hugenholtz, J., \& Smit, S. (2002). Microbial from raw milk for fermented dairy products. International Dairy Journal, 12(2-3), 91-109. http://dx.doi.org/10.1016/S0958-6946(01)00151-0

Zanatta, P., \& Basso, A. (1992). A new approach to the characterization of Streptococcus salivarius subsp. thermophilus based on acidification rates. Le Lait, 72(3), 285-295. http://dx.doi.org/10.1051/lait:1992321

Funding: None. 